\title{
PKM Pendampingan Manajemen Keuangan bagi Mahasiswa Santri Nurul Jadid Selama Masa Pandemi Covid-19
}

\author{
Moh Rasidi ${ }^{1}$, Bashari Alwi ${ }^{2}$, Zaenori ${ }^{3}$, Khairul Umam ${ }^{4}$, \\ Muchammad Lutfillah ${ }^{5}$, Moch Robi'ul Hasan ${ }^{6}$, \\ Edo Cahyo Saputro ${ }^{7}$, Khairunnas ${ }^{8}$ \\ Program Studi Ekonomi Fakultas Sosial dan Humaniora ${ }^{1,2,3,4,5,6,7,8}$ \\ Universitas Nurul Jadid Paiton Probolinggo \\ \{muhammad.rosyidi09@gmail.com\}
}

Submission: 08/07/2021 Received: 30/08/2021 Published: 31/12/2021

\section{Keywords:} covid-19, santri, financial management

Katakunci: covid-19, santri, pengelolaan keuangan

\begin{abstract}
The Covid-19 pandemic has had a negative impact on the economic sector, including the family economy. A part of the family that is economically affected as a result of the Covid-19 pandemic is the guardian of santri or families who are boarding or entrusting their sons-daughters to Islamic boarding schools to study. This condition requires guardians of santri to be able to manage family finances well so that their sons-daughters can continue their education at Islamic boarding schools. However, the santri must also be able to manage their finances well in meeting their daily needs while studying at the Islamic boarding school. Therefore, it is necessary to provide assistance to santri in managing their finances. Thus, this community service activity to assist santri in managing their finances as an effort to meet the daily needs during the Covid-19 pandemic. The results of community service showed that the assistance activity for the financial management of santri during the COVID-19 pandemic was successful, starting from all stages of the implementation of activities that were attended by the assisted santri with the enthusiasm and positive response of the assisted santri in participating in mentoring activities. The assisted santri began to understand that they were able to manage their well finances.
\end{abstract}

\footnotetext{
Abstrak. Pandemi Covid-19 telah memberikan dampak negatif pada sektor ekonomi termasuk ekonomi keluarga. Salah satu bagian dari keluarga yang terdampak ekonominya akibat dari Pandemi Covid-19 adalah wali santri atau keluarga yang sedang memondokkan atau menitipkan putra putrinya di pondok pesantren untuk menuntut ilmu. Kondisi ini menuntut wali santri untuk mampu mengelola keuangan keluarga dengan baik agar putra-putrinya tetap bisa melanjutkan pendidikannya di pondok pesantren. Namun begitu harus ditikuti oleh santri untuk juga mampu mengelola keuangannya dengan baik dalam memenuhi kebutuhan sehari-hari selama menuntut ilmu di pondok pesantren.
} 


\begin{abstract}
Oleh karena itu diperlukan pendampingan terhadap santri dalam mengelola keuangannya. Dengan begitu kegiatan pengabdian masyarakat ini perlu dilakukan dengan tujuan pendampingan terhadap santri dalam mengelola keuangannya sebagai upaya untuk memenuhi kebutuhan sehari-hari di pesantren selama masa pandemi covid-19. Hasil pengabdian masyarakat menunjukkan bahwa Kegiatan pendampingan pengelolaan keuangan santri di masa pandemi covid-19 dapat dikatakan berhasil, mulai dari semua tahap pelaksanaan kegiatan yang diikuti santri-santri peserta dampingan dengan adanya antusiasme dan respon positif santrisantri peserta dampingan dalam mengikuti kegiatan pendampingan. Santri-santri peserta dampingan mulai memahami mampu mengelola keuangannya dengan baik.
\end{abstract}

\title{
1 Pendahuluan
}

Indonesia telah menghadapi bencana pandemi Covid-19 kurang lebih sekitar 12 bulan yang lalu sejak dikonfirmasi pasien pertama pada bulan maret 2020. Hal ini ternyata telah memberikan dampak yang luar biasa tidak hanya pada kesehatan, namun juga pada sektor pendidikan dan ekonomi bagi masyarakat pada umumnya. Beberapa dampak ekonomi yang dirasakan oleh masyarakat diantaranya masyarakat kehilangan pekerjaan dan mata pencaharian akibat terkena PHK, tempat kerja yang sudah tidak beroperasi, atau hanya tutup dalam waktu tertentu. Kondisi ini tentu berpengaruh terhadap pendapatan yang terus menerus berkurang. Sektor ekonomi keluarga pun mengalami dampak dari terjadinya wabah Covid-19. Menteri Keuangan juga menyatakan bahwa wabah Covid-19 akan memperlambat laju pertumbuhan ekonomi Indonesia. Selain ittu sektor rumah tangga akan mengalami penurunan cukup besar dari sisi konsumsi karena tidak lagi melakukan aktivitas sehingga konsumsi akan menurun cukup tajam dari

\section{3,22\% hingga 1,60\% (Warta Ekonomi, 2020)}

Salah satu keluarga yang terdampak ekonominya akibat dari wabah Covid19 adalah wali santri atau keluarga yang sedang memondokkan atau menitipkan putra-putrinya di pondok pesantren. Ditengah wabah Covid-19, wali santri dituntut untuk mampu mengelola keuangannya agar putraputrinya tetap bisa melanjutkan pendidikannya di pondok pesantren. Disisi lain pondok pesantren merespon cepat terhadap adanya dampak ekonomi bagi keluarga wali santri akibat wabah Covid-19. Salah santu pondok pesantren yang merespon dampak wabah Covid-19 terhadap ekonomi keluarga wali santri adalah pondok pesantren Nurul Jadid Paiton Probolinggo Jawa Timur. Respon kongkrit dari pondok pesantren Nurul Jadid adalah 
menciptakan e-Bekal bagi santri. E-Bekal ini merupakan sistem manajemen keuangan santri dalam memenuhi kebutuhan hidup santri seperti makan, jajan, peralatan mandi, ATK dan lain-lain. Dengan e-Bekal, wali santri tidak harus lagi datang ke pondok pesantren untuk mengantar uang/kebutuhan putra putrinya di pondok pesantren, tapi cukup mentransfer uang pada nomor rekening yang sudah disiapkan oleh pondok pesantren, sementara santri mendapatkan kartu e-bekal untuk berbelanja dalam kebutuhan seharihari. Dengan e-Bekal santri dibatasi berbelanja maksimal Rp. 15.000,-/hari (lima belas ribu rupiah per hari).

Wali santri dan Pondok pesantren telah melakukan upaya-upaya kongkrit dalam pengelolaan keuangan santri sebagai akibat dampak dari wabah COVID-19, namun begitu dirasa belum cukup maksimal upaya-upaya tersebut, jika tidak ada upaya dari santri sendiri untuk mengelola keuangannya dengan baik. Oleh karena itu diperlukan pendampingan terhadap santri dalam mengelola keuangannya. Kegiatan pengabdian masyarakat ini perlu dilakukan dengan tujuan pendampingan terhadap santri dalam mengelola keuangannya sebagai upaya untuk memenuhi kebutuhan sehari-hari di pesantren selama masa pandemi covid-19.

\section{Metode}

Kegiatan ini adalah kegiatan Pengabdian Masyarakat yang dilakukan di tingkat Program Studi Program Studi Ekonomi Fakultas Sosial dan Humaniora Universitas Nurul Jadid Paiton Probolinggo, yang dalam pelaksanaanya terdiri atas dosen pembimbing dan kelompok PkM oleh mahasiswa Program Studi Ekonomi Fakultas Sosial dan Humaniora Universitas Nurul Jadid Paiton Probolinggo dan dilaksanakan periode Januari-April 2021. Pelaksanaan kegiatan PkM ini dilaksanakan di Pondok Pesantren Nurul Jadid Paiton Probolinggo Jawa Timur.

Sebagai solusi atas permasalahan yang sedang dihadapi oleh Santri dalam mengelola keuangannya dimasa pandemi covid-19 maka tahapan pelaksanaan kegiatan Pengabdian kepada Masyarakat ini dijalankan sebagai berikut:

1) Identifikasi pekerjaan dan pendapatan wali santri, pengelolaan keuangan santri oleh Pondok Pesantren, kebutuhan hidup dan gaya hidup santri, 
yang bertujuan untuk dapat mengetahui masalah yang dihadapi oleh santri dalam mengelola keuangannya dimasa pandemi covid-19.

2) Persiapan bentuk pendampingan sesuai dengan hasil identifikasi masalah. Tujuannya agar pendampingan yang diberikan tepat dan sesuai dengan masalah yang dihadapi oleh santri dalam pengelolaan keuangannya.

3) Ceramah dan Focus discuss Group (FGD) dengan tema pengelolaan keuangan santri dalam memenuhi kebutuhan sehari-hari selama menuntut ilmu di Pondok Pesantren dimasa Pandemi covid-19. Tujuannya adalah untuk memberikan pemahaman pada santri terhadap pengelolaan keuangan sesuai dengan kebutuhan dan masalah yang dihadapi dimasa Pandemi covid-19.

4) Pendampingan pengelolaan keuangan santri dimasa Pandemi covid-19. Tujuannya adalah agar santri dapat menerapkan pelaksanaan pengelolaan keuangan dengan baik dalam memenuhi kebutuhan hidup sehari-hari selama menuntut ilmu di pondok pesantren di masa Pandemi covid-19

5) Monitoring dan evaluasi pendampingan, yaitu melihat dampak pendampingan santri. Tujuannya adalah untuk melihat dampak pendampingan santri dalam mengelola keuangannya untuk memenuhi kebutuhan hidup sehari-hari selama menuntut ilmu di pondok pesantren di masa Pandemi covid-19. Secara detail adalah mengetahui sejauh mana keberhasilan pendampingan santri dalam pengelolaan keuangannya untuk memenuhi kebutuhan hidup sehari-hari selama menuntut ilmu di pondok pesantren di masa Pandemi Covid-19.

\section{Hasil}

Untuk mencapai tujuan pelaksanaan kegiatan Pengabdian kepada Masyarakat, ada 5 (lima) tahapan yang dilakukan dalam kegiatan ini, yaitu:

\section{Identifikasi Keuangan Santri}

Sebagaimana diketahui, bahwa tujuan kegiatan ini adalah untuk mengetahui masalah yang dihadapi santri dalam pengelolaan keuangannya untuk memenuhi kebutuhan hidup sehari-hari di pondok pesantren pada masa pandemi covid-19. Pelaksanaan kegiatan identifikasi ini dilakukan dengan langsung turun kekantor pesantren khususnya pada bagian keuangan 
pesantren dan tempat belanja santri dalam memenuhi kebutuhan sehari-hari dan bertanya langsung kepada bidang keuangan pesantren terkait upaya pesantren dalam pengelolaan keuangan santri serta juga bertanya langsung pada santri bagaimana mengelola keuangannya dalam memenuhi kebutuhan hidup sehari-hari. Berdasarkan hasil identifikasi pengelolaan keuangan santri dapat dijelaskan bahwa pondok pesantren membuat program e-Bekal. Dengan e-Bekal ini wali santri dapat mentransfer uang untuk kebutuhan putra putrinya dalam memenuhi kebutuhan sehari-hari di pondok pesantren melalui nomor rekening yang sudah disediakan oleh pondok pesantren. Untuk memudahkan penggunaan progran e-Bekal, pondok pesantren menerbitkan Manual Book Aplikasi Bekal Santri NJ.

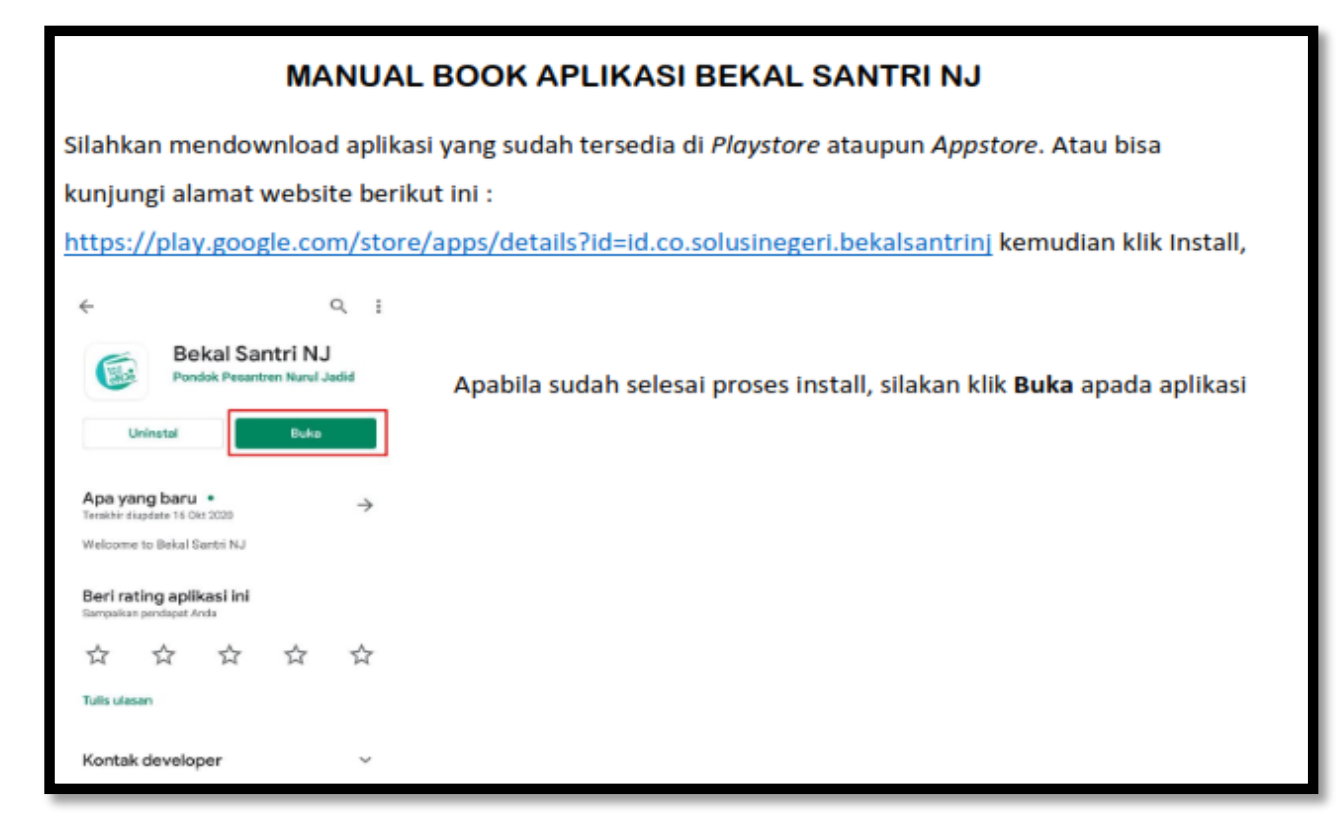

Gambar 1. Manual Book Aplikasi e-Bekal Santri Pondok Pesantren Nuru Jadid

Dengan e-Bekal ini santri hanya dibatasi belanja kebutuhan sehari-hari maksimal Rp. 15.000-/hari. Batas maksimal belanja ini didasarkan pada pekerjaan wali santri. Berikut hasil identifikasi pekerjaan dan pendapatan wali santri pondok pesantren Nurul Jadid.

Tabel 1. Daftar pekerjaan dan pendapatan wali santri pondok pesantren Nurul Jadid 


\begin{tabular}{|c|c|}
\hline Pekerjaan & Pendapatan \\
\hline Petani & $500.000-1.000 .000$ \\
\hline Pedagang & $500.000-2.000 .000$ \\
\hline Wiraswata & $1.000 .000-2.000 .000$ \\
\hline Karyawan swasta & $500.000-1.000 .000$ \\
\hline Buruh & $<500.000$ \\
\hline PNS & $2.000 .000-4.000 .000$ \\
\hline Nelayan & $<500.000$ \\
\hline
\end{tabular}

Di masa pandemi covid-19, kebutuhan sehari-hari santri bertambah, tidak hanya kebutuhan makan dan peralatan mandi dan kebutuhan lainnya, namun kebutuhan santri meningkat seperti harus memenuhi kebutuhan produk-produk kesehatan untuk mencegah penularan covid 19, misalnya pembelian masker, handsanitiser dan perlengkapan kesehatan lainnya. untuk memenuhi kebutuhan makan santri, dapat melalui sistem kosmara (kos makan santri putra) begitupun di putri kosmari (kos makan santri putri) dengan harga Rp. 3.000,-/porsi dan melalui koperasi pesantren. Koperasi pesantren selain menyediakan kebutuhan makan santri juga menyediakan kebutuhan sehari-hari santri seperti misalnya peralatan mandi, nyuci, makan ringan, minuman, ATK, kitab, baju, kaos, sepatu, sandal, peralatan olahraga, peralatan nulis, flashdisk dll.

Pola kehidupan santri yang sebelumnya mendapatkan kesempatan untuk keluar pesantren setiap hari selasa dan jumat untuk sekedar belanja dan berolahraga, semenjak adanya pandemi covid-19 aktivitas tersebut tdak diperbolehkan, karena pembelanjaan santri kini sudah difasilitsi dengan adanyan e-Bekal santri. Jadi hal itu dapat meminimalisir penyebaran covid-19 karena tidak adanya kontak langsung antara santri dengan pihak luar pesantren. Adapaun Pola hidup lainnya seperti makan, santri dibatasi untuk makan hanya 2 kali dalam sehari, yaitu pagi dan sore hari yang biayanya diambilkan lansung dari e-Bekal santri. Namun jika santri ingin makan 3 kali 
dalam sehari atau melebihi batas yang telah ditentukan, tidak lagi diambilkan dari e-Bekal. Dengan begitu ada potensi belanja santri dalam memenuhi kebutuhan sehari-hari melebihi batas limit e-Bekal, sehingga akan mempengaruhi kondisi keuangan keluarga wali santri yang lagi terpukul karena dampak pandemi covid-19

Berdasarkan hasil identifikasi masalah ini, maka diketahui bahwa masalah yang dihadapi oleh santri dalam pengelolaan keuangannya untuk memenuhi kebutuhan sehari-hari dan menjadi prioritas pendampingan adalah terhadap pemahaman santri tentang dampak pandemi covid-19 terhadap ekonomi keluarga dan pendampingan santri dalam pengelolaan keuangannya agar tidak melebihi batas limit e-Bekal. Hasil dari identifikasi masalah ini yang kemudian dilakukan tindak lanjut untuk mempersiapkan bentuk perdampingan dan pelaksanaan pendampingan.

\section{Persiapan Bentuk Pendampingan Santri Dalam Pengelolaan Keuangan di Masa Pandemi Covid-19}

Persiapan bentuk pendampingan disesuaikan dengan hasil identifikasi masalah keuangan santri di masa Pandemi Covid-19 agar pendampingan yang diberikan tepat dan sesuai dengan masalah yang dihadapi. Berdasarkan hasil idenfikasi masalah tersebut di atas, maka bentuk pendampingan yang dipersiapkan, yaitu: ceramah dampak pandemi covid-19 terhadap ekonomi keluarga dan Pengelolaan Keuangan santri dimasa pandemi covid-19, yang dilanjutkan dengan Focus Discuss Group (FGD), pendampingan Pengelolaan Keuangan santri dimasa pandemi covid-19 dan monitoring dan evaluasi terhadap peserta kegiatan pendampingan. Dalam persiapan pendampingan ini, semua yang dibutuhkan dalam pendampingan disiapkan baik materi dan modul ceramah dan diskusi, bahkan perlengkapan yang dibutuhkan dalam ceramah dan pendampingan dan monitoring dan evaluasi.

\section{Ceramah dan Focus Discuss Group (FGD)}

Ceramah dan Focus Discuss Group (FGD) tentang dampak pandemi covid19 terhadap ekonomi keluarga dan Pengelolaan Keuangan santri dimasa pandemi covid-19 bertujuan untuk memberikan pemahaman tentang dampak pandemi covid-19 terhadap ekonomi keluarga, sehingga santri 
memiliki kemampuan yang baik dalam pengelolaan keuangannya untuk memenuhi kebutuhan sehari-hari selama menuntut ilmu di pondok pesantren. Dalam praktiknya, kegiatan ceramah dan FGD ini dilakukan dihalaman asrama santri pada saat santri tidak ada agenda kegiatan pesantren, sehingga santri dapat lebih leluasa dan santai berdiskusi tanpa meninggalkan agenda kegiatan di pesantren.

Saat materi ceramah disampaikan, santri sangat antusias mendengarkan dan mengikuti penyampaian materi dengan baik. Pada saat kegiatan diskusi, mereka tidak ragu-ragu bertanya tentang dampak pandemi covid-19 terhadap ekonomi keluarga dan pengelolaan Keuangan santri dimasa pandemi covid-19. Secara umum, dalam kegiatan ini diberikan materi tentang pengelolaan Keuangan santri dimasa pandemi covid-19 sehingga santri mendapatkan pemahaman tentang manajemen yang baik dalam pengelolaan keuangannya dimasa pandemi covid-19 untuk memenuhi kebutuhan seharihari selama menuntut ilmu di pondok pesantren. Materi yang disampaikan selanjutnya dipraktekkan dan dilanjutkan dengan kegiatan pendampingan.

Hasil dari kegiatan ceramah dan FGD ini adalah meningkatnya pengetahuan santri tentang dampak pandemi covid-19 terhadap ekonomi keluarga dan Pengelolaan Keuangan santri dimasa pandemi covid-19. Santri sudah mengetahui apa yang seharusnya mereka lakukan dalam mengelola keuangannya dimasa pandemi covid-19, seperti berbelanja kebutuhan sehari-hari tidak melebihi batas limit sesuai ketentuan e-Bekal, memprioritaskan belanja kebutuhan sehari-hari pada kebutuhan primer dan esensial saja. 


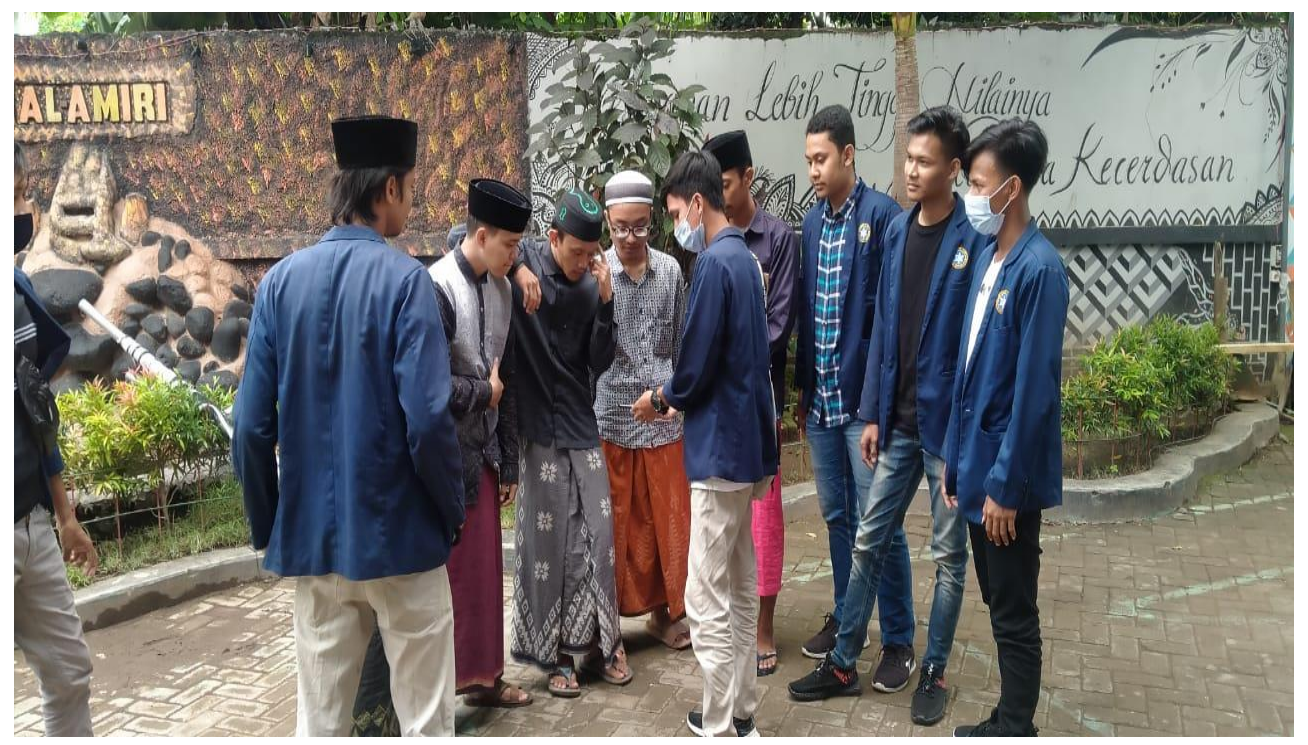

Gambar 2. Ceramah dan FGD dengan Santri-Santri Peserta Dampingan

\section{Pendampingan Pengelolaan Keuangan Santri di Masa Pandemi Covid-19}

Tujuan dilakukannya tahapan ini adalah agar santri dapat menerapkan secara langsung materi yang mereka dapatkan dalam kegiatan ceramah dan FGD untuk mengelola keuangannya dengan baik. Setelah kegiatan ceramah dilakukan, selanjutnya adalah kegiatan pendampingan pengelolaan keuangan santri, dimana santri mempraktekkan secara langsung tentang pengelolaan keuangannya.

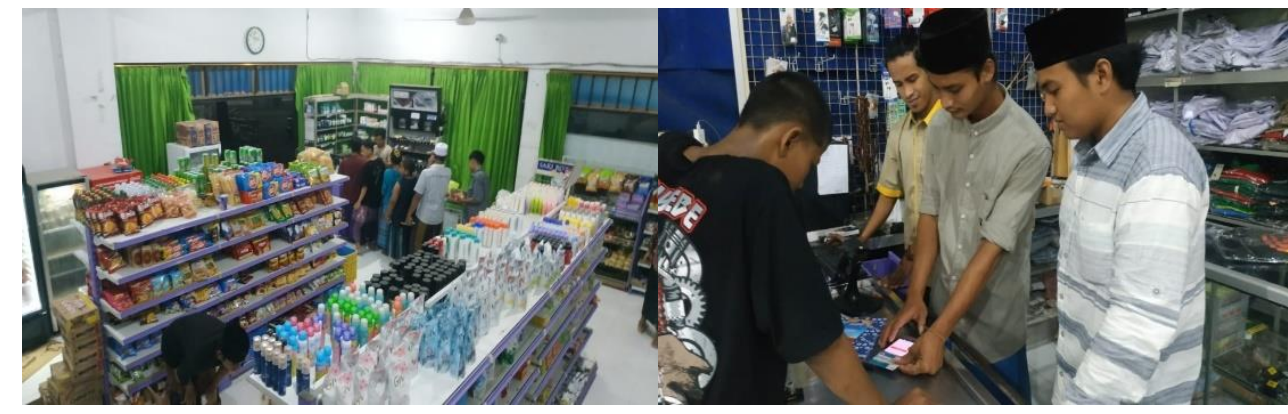

Gambar 3. Pendampingan Santri Peserta Dampingan Dalam Berbelanja Kebutuhan SehariHari Menggunakan e-Bekal 
Praktek pengelolaan keuangan yang di dilakukan adalah berbelanja kebutuhan sehari-hari (diluar kebutuhan makan) tidak melebihi batas limit sesuai ketentuan e-Bekal, memprioritaskan belanja kebutuhan sehari-hari pada kebutuhan primer dan esensial saja. Limit e-Bekal berkisar Rp. 10.000,s/d Rp. 20.000,- dan limit tersebut ditentukan oleh wali santri sendiri.

\section{Monitoring dan Evaluasi Pendampingan}

Monitoring dan evaluasi terhadap dampak pendampingan pengelolaan keuangan santri dimasa pandemi covid-19 bertujuan untuk melihat secara langsung dampak dari kegiatan pendampingan yang sudah dilakukan dan terus melatih dan membiasakan santri dalam mengelola keuangannya dengan baik, efktif dan efisien. Setelah kegiatan pendampingan ini dilakukan, maka selanjutnya proses monitoring dan evaluasi dilakukan untuk melihat keefektifan penerapan pendampingan ini. Dari hasil monitoring dan evaluasi ini, diperoleh saran bahwa dalam berbelanja untuk memenuhi kebutuhan sehari-hari di pondok pesantren untuk belajar dan membiasakan menahan diri agar tidak berbelanja yang tidak primer dan esensial, hal ini sebagai upaya membantu ekonomi keluarga yang lagi terdampak pandemi covid-19 dan sekaligus membantu suksesnya program pondok pesantren yaitu program eBekal.

Hasil dari kegiatan ini adalah meningkatnya pemahaman dan kemampuan santri tentang dampak pandemi covid-19 terhadap ekonomi keluarga dan Pengelolaan Keuangan santri dimasa pandemi covid-19. Menurut Susanti, et.al., (2021) pada pandemi Covid-19 saat ini, mengharuskan santri untuk mulai menambah pemahaman dan kemampuan dalam mengelola keuangannya agar mampu bertahan dalam situasi pandemi Covid-19. Melalui kegiatan ini, dapat dipecahkan masalah yang santri hadapi dalam pengelolaan keuangannya di masa pandemi covid-19. Utamanya adalah dilihat dari dampak pendampingan terhadap masalah keuangan santri, sehingga dapat diketahui peningkatan pemahaman tentang pengelolaan keuangan dimasa pandemi covid-19. Berdasarkan hasil kegiatan pengabdian kepada masyarakat pada santri di Nurul Jadid, pemahaman santri yang mengikuti kegiatan ini meningkat, yaitu tentang dampak pandemi covid-19 terhadap ekonomi keluarga dan Pengelolaan Keuangan santri dimasa pandemi covid19. 
Kegiatan pendampingan ini dapat berjalan dengan baik karena adanya antusias dari santri mengikuti kegiatan ini sehingga mereka dapat memahami dampak pandemi covid-19 terhadap ekonomi keluarga dan Pengelolaan Keuangan santri dimasa pandemi covid-19 dengan baik. Demikian juga keinginan dan kemauan santri untuk melakukan pengelolaan keuangannya dengan baik, agar dampak covid-19 terhadap ekonomi keluarga/wali santri tidak berdampak pada tidak berlanjutnya proses pendidikan santri di pondok pesantren.

Antusiasme santri ditunjukkan juga dalam kegiatan FGD dengan banyaknya pertanyaan yang diajukan. Di samping itu terdapat juga kendala dalam kegiatan pengabdian kepada masyarakat yaitu karena kurangnya pemahaman santri tentang dampak covid-19 terhadap ekonomi keluarga karena minimnya informasi yang mereka terima dan kemampuan santri dalam mengelola keuanngannya karena belum bisa menahan diri untuk tidak berbelanja kebutuhan non primer dan non esensial, seperti yang disampailkan oleh Kozuma (2017) bahwa minimnya literasi keuangan oleh pelajar (santri) berdampak pada belum mampunya mengendalikan diri dalam bersikap konsumtif. Sarswati dan Nugroho (2021) menambahkan bahwa melalui penguatan literasi keuangan pada masa pandemi Covid-19 ini diharapkan generasi muda (santri) dapat memiliki kemampuan merencanakan dan mengelola keuangannya dengan baik dan bijak. Oleh karena itu pengabdi berusaha disiplin dengan membimbingdan membiasakan santri untuk beradaptasi dengan situasi ekonomi keluarga dimasa pandemi covid-19 dalam berbelanja untuk memenuhi kebutuhan sehari-hari dipondok pesantren.

\section{Pembahasan}

Berdasarkan hasil monitoring dan evaluasi pendampingan pengelolaan keuangan santri dimasa pandemi covid-19, kegiatan pendampingan dapat berjalan dengan baik dan mendapat sambutan yang baik dari santri-santri peserta dampingan. Kegiatan pendampingan ini dapat dikatakan berhasil, mulai dari semua tahap pelaksanaan kegiatan yang diikuti santri-santri peserta dampingan dengan adanya antusiasme dan respon positif santrisantri peserta dampingan dalam mengikuti kegiatan pendampingan. Adanya kesesuaian materi dengan masalah yang dihadapi untuk meningkatkan 
pemahaman dan pengetahuan tentang dampak pandemi covid-19 terhadap ekonomi keluarga dan pengelolan keuangan santri dimasa penademi covid19. Santri-santri peserta dampingan mulai memahami dampak pandemi covid-19 terhadap ekonomi keluarga dan sudah mampu mengelola keuangannya dengan baik, hal ini ditunjukkan dengan berbelanja kebutuhan sehari-hari di prioritaskan pada kebutuhan primer dan esensial serta sesuai dengan batas limit yang ditetapkan dalam e-Bekal.

Namun begitu dalam kegiatan pendampingan ditemukan beberapa permasalahan yang berpotensi menghambat dan mengganggu santri dalam mengelola keuangan dengan baik efektif dan efisien, yaitu perbedaan karakter dan gaya hidup, perbedaan latar belakang ekonomi keluarga dan perbedaan signifikasi dampak pandemi covid-19 pada ekonomi keluarga bagi masing-masing santri. Hal ini dijelaskan olh Parmitasari et.al., (2018) bahwa gaya hidup hedonisme mempengaruhi pengelolaan keuangan generasi muda. Baroroh (2019) menambahkan bahwa Gaya hidup dan pendapatan orang tua akan mempengaruhi perilaku keuangan santri. Oleh karena itu Kegiatan pendampingan ini diharapkan dapat dilanjutkan dengan upaya adanya dan kerja sama yang baik antara pesantren dan wali santri untuk mengatasi berbagai permasalahan yang mungkin muncul kemudian yang dapat menghambat terwujudnya pengelolaan keuangan santri yang baik, efektif dan efisien dalam memenuhi kebutuhan hidup sehari-hari di pondok pesantren selama pandemi covid-19.

\section{Kesimpulan}

Kegiatan pendampingan pengelolaan keuangan santri di masa pandemi covid-19 dapat dikatakan berhasil, mulai dari semua tahap pelaksanaan kegiatan yang diikuti santri-santri peserta dampingan dengan adanya antusiasme dan respon positif santri-santri peserta dampingan dalam mengikuti kegiatan pendampingan. Santri-santri peserta dampingan mulai memahami mampu mengelola keuangannya dengan baik, hal ini ditunjukkan dengan berbelanja kebutuhan sehari-hari di prioritaskan pada kebutuhan primer dan esensial serta sesuai dengan batas limit yang ditetapkan dalam eBekal. Namun begitu dalam kegiatan pendampingan ditemukan beberapa permasalahan yang berpotensi menghambat dan mengganggu santri dalam mengelola keuangan dengan baik efektif dan efisien, yaitu perbedaan 
karakter dan gaya hidup, perbedaan latar belakang ekonomi keluarga dan perbedaan signifikasi dampak pandemi covid-19 pada ekonomi keluarga bagi masing-masing santri, sehingga kegiatan pendampingan ini diharapkan dapat dilanjutkan dengan upaya adanya dan kerja sama yang baik antara pesantren dan wali santri untuk mengatasi berbagai permasalahan yang mungkin muncul kemudian yang dapat menghambat terwujudnya pengelolaan keuangan santri yang baik, efektif dan efisien dimasa pandemi covid-19.

\section{Pengakuan}

Ucapan terimaksih disampaikan kepada semua pihak yang telah banyak membantu kegiatan pengabdian kepada masyarakat ini, diantaranya bagian keuangan pondok pesantren dan penanggung jawab pusat belanja kebutuhan sehari-hari santri.

\section{Referensi}

Anggiruling, D. O. 2016. Evaluasi Sistem Penyelenggaraan Makanan Di Pondok Pesantren Al-Musyarrofah.

Baroroh. M. A. 2019. Pengaruh Literasi Keuangan, Gaya Hidup Dan Pendapatan Orang Tua Terhadap Perilaku Manajemen Keuangan Santri Di Pondok Pesantren Madrosatul Qur'anil Aziziyah Semarang. Skripsi. Fakultas Ekonomi Dan Bisnis Islam Universitas Islam Negeri Walisongo Semarang

Doriza, Shinta. 2015. Ekonomi Keluarga. Bandung: PT Remaja Rosdakarya Offset.

Hadziq, M., \& Nafis, M. 2017. Implikasi Pendampingan Mitra Usaha Kecil Menengah (Studi Pendekatan Melalui Pelatihan Laporan Keuangan Sederhana). Jurnal Middle East and Islamic Studies, 396-409.

Ismail, 2002. Dinamika Pesantren danMadrasah, Yogyakarta, Pustaka BelajarOffset

Kompas. 2020. Survei SMRC: Dampak Covid-19, 59 Persen Responden Anggap Ekonomi Rumah Tangga Bakal Memburuk. https://nasional.kompas.com/read/2020/05/12/15280211/survei. 
smrcdampak-covid-19-59-persen-responden-anggap-ekonomi-rumahtangga

Kozuma. T. 2017. Pengaruh Literasi Terhadap Perilaku Santri Dalam Mengelola Keuangan. Kumparan. https://kumparan.com/teddykozuma/pengaruh-literasi-terhadap-perilaku-santri-dalam-mengelola-

Masruri. M, H. Ali dan K. I. Rosadi. 2021. Pengelolaan Keuangan Dalam Mempertahankan Kualitas Pondok Pesantren Selama Pandemi Covid-19. J. Ilmu Manajemen Terapan. 2(5):644-657

Mastuhu. 1994. Dinamika Sistem PendidikanPesantren, Jakarta. INIS

Nurcholis Madjid. 1997. Bilik-Bilik Pesantren Sebuah Potret Perjalanan,Jakarta: Paramadina.

Okezone. 2020. kecemasan Masyarakat Mulai Bergeser Dari Corona Ke Masalah Ekonomi.

Parmitasari. R. D. A, Z. Alwi dan S. Sunarti. 2018. Peran Kecerdasan Spiritual Dan Gaya Hidup Hedonisme Dalam Manajemen Keuangan Pribadi Mahasiswa Di Kota Makassar. J Mannajemen. 5(2):147-162

Saraswati. A.M, dan A. W. Nugroho. 2021. Perencanaan Keuangan dan Pengelolaan Keuangan Generasi Z di Masa Pandemi COVID-19 melalui Penguatan Literasi Keuangan. J Warta LPM. 24(2):309-318.

Sholiha YA. 2013. Gambaran Pola Konsumsi Dan Tingkat Kepuasan Santri Putri Terhadap Hidangan Di Yayasan Pondok Pesantren Hidayatullah Makassar. Media Gizi Pangan ;15(1):5-7.

Susanti. A, B. Istiyanto dan T. R. 2021. Pamikatsin Pemberdayaan Kewirausahaan Santri Pondok Pesantren Ad-Dhuha di Masa Pandemi Covid-19. J. Adidas. 2(4):790-800.

Warta Ekonomi. 2020. Menkeu: Pandemi Corona Pukul Konsumsi Rumah Tangga. $\quad$ https://www.wartaekonomi.co.id/read279104/menkeu pandemi-corona-pukulkonsumsi-rumah-tangga 